УДК 618.36+618.3]-005-008.6

DOI 10.11603/24116-4944.2020.2.11847

\author{
๑ Л. Б. Маркін, Т. В. Фартушок \\ Лъвівсъкий національний медичний університет ілені Данила Галицького

\section{ПРОФІЛАКТИКА РОЗЛАДІВ ФУНКЦІОНАЛЬНОГО ДИФЕРЕНЦІЮВАННЯ ПЛАЦЕНТИ}

Мета дослідження - можливості профрілактики ускладнень гестаційного процесу.

Матеріали і методи. Першу групу спостереження склали 25 жінок, у яких при 28-30-тижневому терміні вагітності виникли початкові ознаки порушення життєдіяльності плода. Другу групу склали 25 жінок, яким з метою профрілактики передчасних пологів із 22-24-тижневого терміну вагітності призначали вагінально мікронізований прогестерон прогінорм геста 200 мг на добу. Третю групу склали 25 вагітних групи ризику фрунціонального диференціювання плаценти, які 322 тижня вагітності приймали прогестерон 200 мг на добу вагінально. Оцінку розвитку плода проводили за допомогою ультразвукової системи SA-8000 EX. Мінімальний об'єм фетометрії включав визначення біпарієтального розміру головки (БПР), довжини стегнової кістки (ДС) і середнього діаметра живота (ДЖ), визначали також кількість генералізованих (ГР) і тривалість епізодів постійних дихальних (ДР) рухів плода, використовували індекс ГР та індекс ДР. Реєстрацію кардіотахограми проводили монітором типу 8030 А фрірми «Hewlett-Packard».

Результати дослідження та їх обговорення. Проведені дослідження показали, що середній показник біофізичного просрілю плода (БПП) у вагітних першої групи дорівнював $(5,6 \pm 0,3)$ бала. При цьому базальна частота серцевих скорочень (БЧСС) у плода складала $(171,3 \pm 4,3)$ уд./Хв, спостерігався ундулюючий тип варіабельності. Амплітуда миттєвих осциляцій $(3,4 \pm 0,5)$ уд./Хв, частота - $(3,0 \pm 0,4)$ уд./Хв, реєструвалися поодинокі $(2,2 \pm 0,3)$ акцелерації помірної амплітуди $((16,5 \pm 0,8)$ уд./хв) і тривалості $((17,8 \pm 1,6)$ c). У 24 \% випадків відмічені окремі $(1,5 \pm 0,4)$ децелерації. Амплітуда останніх складала $(18,5 \pm 1,7)$ уд./хв, тривалість $(20,4 \pm 1,9)$ с. Було виявлено лише $(2,3 \pm 0,5)$ ГР, поодиноких короткочасних $((25,5 \pm 3,4)$ с) епізодів постійних ДР. Індекс ГР складав $(2,3 \pm 0,4) \%$, індекс ДР - $(2,6 \pm 0,4) \%(p<0,05)$. У першій групі при наявності у $48 \%$ випадків плацента відрізнялась високою ехогенністю. У вагітних другої групи виявили фетальний дистрес у 12 \% випадків. У третій групі розлади функціонального диференціювання плодової частини плаценти мали місце у 24 \% вагітних.

Висновки. Призначення прогінорм геста вагітним групи ризику розладів фрункціонального дисреренціювання плодової частини плаценти позитивно впливає на перебіг процесів функціонального диференціювання плодової частини плаценти, забезпечує профрілактику фетального дистресу.

Ключові слова: функціональне диференціювання плодової частини плаценти; дистрес; ехогенність; профрілактика.

ПРОФИЛАКТИКА НАРУШЕНИЙ ФУНКЦИОНАЛЬНОГО ДИФФЕРЕНЦИРОВАНИЯ ПЛАЦЕНТЫ

Цель исследования - возможности профилактики осложнений гестационного процесса.

Материалы и методы. Первую группу наблюдения составили 25 женщин, у которых при 28-30-недельном сроке беременности возникли начальные признаки нарушения жизнедеятельности плода. Вторую группу составили 25 женщин, которым с целью профилактики преждевременных родов с 22-24-недельного срока беременности назначали вагинально микронизированный прогестерон Leon Farma Sa Spain прогинорм геста 200 мг в сутки вечером перед сном. Третью группу составили 25 беременных группы риска фрункционального дифференцирования плаценты, которые с 22 недели беременности принимали прогестерон 200 мг в сутки вагинально. Оценку развития плода проводили с помощью ультразвуковой системы SA-8000 EX. Регистрацию кардиотахограммы проводили монитором типа 8030 A формы «Hewlett-Packard».

Результаты исследования и их обсуждение. Проведенные исследования показали, что средний показатель биофризического профиля плода (БПП) у беременных первой группы равнялся $(5,6 \pm 0,3)$ балла. При этом базальная частота сердечных сокращений (БЧСС) у плода составляла $(171,3 \pm 4,3)$ уд./мин, преимущественно наблюдался ундулирующий тип вариабельности ЧСС плода. Амплитуда мгновенных осцилляций равнялась $(3,4 \pm 0,5)$ уд./мин, частота - $(3,0 \pm 0,4)$ уд./мин, регистрировались единичные $(2,2 \pm 0,3)$ акцелерации умеренной амплитуды $((16,5 \pm 0,8)$ уд./мин) и продолжительности $((17,8 \pm 1,6)$ c). В 24 \% случаев отмечены отдельные $(1,5 \pm 0,4)$ децелерации. Амплитуда последних составляла $(18,5 \pm 1,7)$ уд./мин, продолжительность - $(20,4 \pm 1,9)$ с. Было обнаружено лишь $(2,3 \pm 0,5)$ гд, редких кратковременных $((25,5 \pm 3,4)$ с) эпизодов постоянных ДД. Индекс ГД составлял $2,3 \pm 0,4 \%$, а индекс ДД плода - $(2,6 \pm 0,4) \%(p<0,05)$. В первой группе наблюдения в $48 \%$ случаев плацента отличалась высокой эхогенностью. У беременных второй группы обнаружили наличие фетального дистресса в 12 \% случаев. В третьей группе расстройства функционального дифференцирования плодовой части плаценты имели место у $24 \%$ беременных.

Выводы. Назначение прогинорм геста беременным положительно влияет на ход процессов функционального диффреренцирования плодовой части плаценты, обеспечивает профилактику фетального дистресса.

Ключевые слова: фрункциональное дисфференцирование плодовой части плаценты; дистресс; эхогенность; профилактика.

PREVENTION OF DISORDERS OF FUNCTIONAL DIFFERENTIATION OF THE PLACENTA

The aim of the study - the possibility of prevention of complications of the gestational process.

Materials and Methods. The first group of observations consisted of 25 women who at 28-30 weeks of gestation had initial signs of fetal dysfunction. The second group consisted of 25 women who were prescribed vaginally micronized progesterone proginorm gesta $200 \mathrm{mg}$ per day to prevent premature birth from 22-24 weeks of gestation. The third group consisted of 25 pregnant women 
at risk of functional differentiation of the placenta, who from 22 weeks of pregnancy took progesterone 200 mg per day vaginally. Evaluation of fetal development was performed using an ultrasound system SA-8000 EX. Cardiotachogram was recorded with a Hewlett-Packard 8030 A monitor.

Results and Discussion. The average biophysical profile of the fetus (BPF) in pregnant women of the first group was (5.6 \pm 0.3$)$ points. The basal heart rate $(\mathrm{BHR})$ was $(171.3 \pm 4.3) \mathrm{bpm}$, there was undulating type of variability. Amplitude of instantaneous oscillations - $(3.4 \pm 0.5) \mathrm{bpm}$, frequency - $(3.0 \pm 0.4) \mathrm{bpm}$, single $(2.2 \pm 0.3)$ accelerations of moderate amplitude were registered $(16.5 \pm 0.8) \mathrm{bpm})$ and duration (17.8 \pm 1.6$) \mathrm{s})$. In $24 \%$ of cases, individual (1.5 \pm 0.4$)$ decelerations were noted. In the first group, in $48 \%$ of cases the placenta was highly echogenic. In women of the second group found fetal distress in $12 \%$ of cases. In the third group, disorders of functional differentiation of the fetal part of the placenta occurred in $24 \%$ of pregnant women.

Conclusions. Appointment of proginorm gesta to pregnant women has a positive effect of functional differentiation of the fetal part of the placenta, provides prevention of fetal distress.

Key words: functional differentiation of the fetal part of the placenta; distress; echogenicity; prevention.

ВстУП. Плацента виконує роль специфічного виконуючого органа матері та плода, рефлексогенної зони, що забезпечує адекватну реалізацію взаємовідносин між матір'ю та плодом [1-3]. Роль її надзвичайно велика як при фрізіологічному перебігу вагітності, так і при несприятливих умовах внутрішньоутробного розвитку плода, що пов'язані з ускладненнями вагітності та пологів, а також із захворюваннями матері [4-6].

Функції плаценти різноманітні. Через неї відбувається живлення та газообмін плода, виділення продуктів метаболізму, фрормування гормонального та імунного статусу плода [7-9]. У процесі вагітності плацента замінює плоду недостатність функції гематоенцефралічного бар'єра, захищаючи його нервові центри і весь організм від дії токсичних фракторів [10-12].

Принципове значення для нормального перебігу гестаційного процесу, адекватної реалізації взаємовідношень між материнським організмом та плодом має морфоорункціональний стан плаценти. Плацента змінюється в міру прогресування вагітності, забезпечуючи зростаючі потреби оретального організму. Судинна сітка плаценти складається 3 двох систем: матково-плацентарної та плодової. Матково-плацентарні артерії із стінок матки занурюються у децидуальну оболонку і виливають свою артеріальну кров безпосередньо у міжворсинчастий простір, звідки венозна кров відтікає назад по матковоплацентарних венах.

Формування плодово-плацентарного і матковоплацентарного кровотоку спостерігається до кінця I триместру вагітності, однак до цього періоду онтогенезу у морфофункціональному відношенні плацента залишається ще незрілою. Надзвичайно важливим етапом морфогенезу плаценти $є$ гестаційна трансформація плодово-плацентарного кровотоку.

Другий триместр вагітності характеризується ростом і диференціюванням плодового русла кровотоку ("феталізація" плаценти), з якими тісно пов'язані зміни строми і трофробласта ворсинчастого хоріона. Вказані зміни іноді називають "срункціональним дисреренціюванням" плаценти, оскільки вони спрямовані на задоволення зростаючих потреб плода у кисні і необхідних поживних речовинах. У цьому періоді морфоорункціональні перетворення плаценти проявляються зближенням материнського і плодового кровотоків і збільшенням поверхні структур, які беруть участь у безпосередньому контакті між ними.

Серед численних методів вивчення структури та функції плаценти (морфологічний, гістохімічний, радіоізотопний, гормональний та ін.) особливе місце належить ультразвуковому скануванню у зв'язку із його простотою, нешкідливістю і високою інорормативністю [13-15]. При цьому спостерігається еволюція ехографрічного малюнка плацентарної тканини, її ехогенності, властивості відбивати ультразвукові хвилі $[16,17]$. Дослідження ехогенності плацентарної тканини надає достатньо об'єктивну інфрормацію про розвиток плаценти, перебіг процесів ії̈ функціонального диференціювання $[18,19]$.

Ехогенність печінки плода не змінюється протягом усієї вагітності, тому здатність плаценти відбивати ультразвукові хвилі доцільно порівнювати із звукопровідністю печінки плода $[20,21]$.

У нормі при 28-30-тижневому терміні вагітності ехосигнал від плаценти і печінки плода має однакову інтенсивність. Остання перебуває у повній відповідності 3 наявністю достатнього фрункціонального диференціювання плаценти плода. При розладах фрункціонального диференціювання плаценти остання вирізняється високою ехогенністю. Відбиваюча здатність плаценти перевищує таку печінки плода. На екрані монітора ехоструктура плаценти виглядає світлішою за ехоструктуру печінки плода [22, 23].

Ускладнення вагітності та екстрагенітальні захворювання матері нерідко призводять до різних змін у плаценті, порушуючи її будову і функцію, що, в свою чергу, може негативно відображатися на стані плода, при цьому нерідко виявляється специфіка змін у плаценті, що залежить від характеру порушень в організмі матері $[24,25]$.

Враховуючи зазначене, виявилось доцільним визначити провідні чинники ризику розладів функціонального диференціювання плаценти, можливості профрілактики вказаного ускладнення гестаційного процесу.

МЕТА ДОСЛІДЖЕННЯ - ВИзНачИти провідні чинники ризику розладів функціонального диференціювання плаценти, можливості профрілактики ускладнень гестаційного процесу.

МАТЕРІАЛИ ТА МЕТОДИ. Першу групу спостереження склали 25 жінок, у яких при 28-30-тижневому терміні вагітності виникли початкові порушення життєдіяльності плода.

Другу групу склали 25 жінок з анамнезом, обтяженим ускладненнями антенатального періоду плода (дистрес, загибель плода) на тлі порушень розвитку плаценти, яким з метою профрілактики передчасних пологів із 22-24-тижневого терміну вагітності призначали вагінально мікронізований прогестерон Leon Farma Sa Spain прогінорм геста (200 мг на добу ввечері перед сном).

Третю групу склали 25 вагітних групи ризику функціонального диференціювання плаценти, які 322 тижня вагітності приймали прогестерон (200 мг на добу, вагінально). 
Оцінку розвитку плода проводили за допомогою ультразвукової системи «SA-8000 EX». Мінімальний обов'язковий об'єм фетометрії включав визначення біпарієтального розміру головки (БПР), довжини стегнової кістки (ДС) і середнього діаметра живота (ДЖ). Вимірювання БПР здійснювали від зовнішньої поверхні верхнього контуру до внутрішньої поверхні нижнього контуру тім'яних кісток перпендикулярно М-ехо. За ДС плода приймали максимальний поздовжній розмір кальцифрікованого діафізу стегнової кістки. ДЖ являє собою середнє арисметичне з передньо-заднього та поперечного діаметру живота. Вимірювання проводили від зовнішніх контурів поперечного перерізу тулуба плода. Об'єм розширеної фетометрії включав визначення окружності головки (ОГ) й окружності живота (ОЖ) плода. Обчислювали також відношення ОГ до ОЖ і ДС до ОЖ. При визначенні ОГ і ОЖ плода використовували фоомули розрахунку, запропоновані В. Н. Демидовим і співавт. (1990): для ОГ - (БПР+ЛПР) х 1,57, де ЛПР - лобно-потиличний розмір головки, а для ОЖ - (ПЗРЖ+ПРЖ) х 1,57, де ПЗРЖ і ПРЖ - передньозадній і поперечний розміри живота плода.

Протягом 30-хвилинного ультразвукового обстеження визначали кількість генералізованих (ГР) і тривалість епізодів постійних (що повторювалися не рідше ніж через 6 с) дихальних (ДР) рухів плода. 3 метою об'єктивізації дослідження рухової активності плода використовували відносні показники: індекс ГР, який визначали як відсоткове співвідношення загальної тривалості ГР і часу дослідження, та індекс ДР - відсоткове співвідношення тривалості постійних ДР плода і часу дослідження. Проводили оцінку м'язового тонусу (МТ) плода, звертаючи увагу на його здатність повертатись до стану фрлексії після виконання рухів (Л. Б. Маркін і співавт., 1993).

За даними ехографрічної картини, робили висновок про кількість навколоплодових вод. За методикою J. Phelan та співавт. (1987), обчислювали індекс амніотичної рідини. При цьому порожнину матки поділяли на чотири квадранти (біла лінія живота розділяла матку на праву та ліву половини, лінія на рівні пупка - на верхню та нижню частини). У подальшому визначали вертикальний розмір найбільшої кишені амніотичної рідини у кожному квадранті. Сума чотирьох значень являє собою індекс амніотичної рідини.

Реєстрацію кардіотахограми (КТГ) плода проводили монітором типу 8030 A фрірми «Hewlett-Packard». Вагітним надавали напівфровлерівського положення. Запис КТГ здійснювали протягом 20 хв на стрічці, що рухалася зі швидкістю 1 см/хв. При аналізі КТГ враховували такі показники: базальну частоту серцевих скорочень (БЧСС), амплітуду миттєвих осциляцій (АМО), амплітуду повільних осциляцій (АповО), частоту повільних осциляцій (ЧповО), частоту виявлення і тривалість ділянок монотонності ритму, кількість, амплітуду і тривалість акцелерацій і децелерацій частоти серцевих скорочень (ЧСС) плода. При інтерпретації отриманих даних враховували рекомендації А. А. Зелинского и соавт. (2001).

Комплексну оцінку біофрізичного профрілю плода (БПП) проводили за шкалою, наведеною у відповідних методичних рекомендаціях МОЗ України (2006).

При ультразвуковій плацентографрії вивчали ехогенність плацентарної тканини. Здатність плаценти відбивати ультразвукові хвилі порівнювали із звукопровідністю печінки плода.
Статистичну обробку одержаних результатів здійснювали з використанням сучасних методів варіаційної статистики за допомогою стандартних програм статистичного аналізу Microsoft Excel 5.0.

РЕЗУЛЬТАТИ ДОСЛІДЖЕННЯ ТА ЇХ ОБГОВОРЕННЯ. Проведені дослідження показали, що середній показник БПП у вагітних першої групи спостереження дорівнював $(5,6 \pm 0,3)$ бала. При цьому БчСС у плода складала $(171,3 \pm 4,3)$ уд./хв. Переважно спостерігали ундулюючий тип варіабельності чСС плода. Амплітуда миттєвих осциляцій дорівнювала $(3,4 \pm 0,5)$ уд./хв, частота - $(3,0 \pm 0,4)$ уд./хв. За 20-хвилинний період спостереження реєстрували поодинокі $(2,2 \pm 0,3)$ акселерації помірної амплітуди $((16,5 \pm 0,8)$ уд./хв) і тривалості $((17,8 \pm 1,6)$ с). Тривалість ділянок монотонності ритму ЧСС плода дорівнювала $(30,4 \pm 3,6)$ \% запису. У 24 \% випадків відмічено окремі $(1,5 \pm 0,4)$ децелерації. Амплітуда останніх складала $(18,5 \pm 1,7)$ уд./хв, тривалість - $(20,4 \pm 1,9)$ с.

Про пригнічення адаптивних рухових функцій плода свідчила наявність лише $(2,3 \pm 0,5)$ ГР, поодиноких короткочасних $((25,5 \pm 3,4)$ с) епізодів постійних ДР за 30 хв спостереження. Індекс ГР складав $(2,3 \pm 0,4) \%$, а індекс ДР плода - $(2,6 \pm 0,4) \%(p<0,05)$. Після виконання рухів плід протягом значного часу не повертався до стану фрлексії, його кінцівки та хребет частково або повністю залишались у розігнутому стані.

При наявності дистресу плода у 20 \% вагітних мало місце маловоддя. У цих випадках навколоплодові води не візуалізувались у більшій частині порожнини матки. Найбільший вертикальний розмір вільної ділянки амніотичної рідини не перевищував 2 см, індекс навколоплодових вод був менше 5 процентилів.

Слід зазначити, що у 16 \% випадків при наявності сретального дистресу мала місце асиметрична форма затримки розвитку плода. Спостерігали переважне відставання розмірів внутрішніх органів черевної порожнини плода, особливо печінки, у зв'язку з чим мала місце невідповідність розмірів живота плода терміну вагітності. Відмічали достовірне підвищення відношень ОГ до ОЖ та ДС до ОЖ. Величина ОГ/ОЖ складала 1,28, а ДС/ОЖ $-0,27$, що перевищували такі при нормальному розвитку плода $(p<0,05)$.

Особливої уваги заслуговує той фракт, що в першій групі спостереження при наявності порушень життєдіяльності плода у 48 \% випадків плацента вирізнялась високою ехогенністю, її відбиваюча здатність перевищувала таку печінки плода. Ехоструктура плаценти виглядала на екрані монітора світлішою за ехоструктуру печінки плода, що свідчило про наявність розладів функціонального диференціювання плодової частини плаценти.

Дослідження акушерсько-гінекологічного анамнезу, особливостей репродуктивної системи, аналіз екстрагенітальних захворювань, ускладнень гестаційного процесу у вагітних першої групи спостереження показали, що провідними чинниками ризику розладів функціонального диференціювання плаценти є вік матері до 18 і більше 30 років, соціальне неблагополуччя, у тому числі нутритивна недостатність, високі психоемоційні навантаження, важка срізична праця і профресійні шкідливості, тютюнокуріння, порушення менструального циклу, хронічний запальний процес внутрішніх статевих органів, гострі інфеекційні захворювання під час даної вагітності. 
Комплексна оцінка стану плода у вагітних другої групи спостереження виявила наявність фретального дистресу, зумовленого розладами функціонального диференціювання плодової частини плаценти, у 12 \% випадків. При цьому $32 \%$ жінок належали до вагітних групи ризику розладів фрункціонального дисреренціювання плодової частини плаценти.

У третій групі спостереження розлади срункціонального диореренціювання плодової частини плаценти і порушення життєдіяльності плода мали місце у 24 \% вагітних.

ВИСновКИ. 1. Розлади функціонального диференціювання плодової частини плаценти зумовлюють порушення життєдіяльності плода, негативно впливають на його подальший розвиток.

2. Провідними чинниками ризику розладів фрункціонального диференціювання плодової частини плаценти $€$ вік матері до 18 і більше 30 років, соціальне неблагополуччя, у тому числі нутритивна недостатність, високі психоемоційні навантаження, важка фрізична праця і професійні шкідливості, тютюнокуріння, порушення менструального циклу, хронічний запальний процес внутрішніх статевих органів, гострі інфекційні захворювання під час даної вагітності.

3. Важливу інформацію про стан процесів фрункціонального диференціювання плодової частини плаценти надає порівняльний аналіз із ехогенності плацентарної тканини і печінки плода.

4. Призначення прогінорм геста вагітним групи ризику розладів фрункціонального дисреренціювання плодової частини плаценти позитивно впливає на перебіг процесів фрункціонального диференціювання плодової частини плаценти, забезпечує профрілактику фретального дистресу.

ПЕРСПЕКТИВИ ПОДАЛЬШИХ ДОСЛІДЖЕНЬ. СУТТєвий науково-прикладний інтерес являє собою поглиблене дослідження особливостей матково-плацентарного та плацентарно-плодового кровотоків при розладах фрункціонального диференціювання плодової частини плаценти.

\section{СПИСОК ЛІТЕРАТУРИ}

1. Милованов А. П. Морфологические особенности ультразвуковых критериев стадии зрелости плаценты при физиологическом течении беременности / А. П. Милованов М. А. Фукс, М. Л. Чехонацкая // Акушерство и гинекология. - 1990. - № 5. - С. 19-22.

2. Агеева М. И. Допплерограсрия плацентарного кровообращения : пособ. для врачей / М. И. Агеева, И. А. Озерская Е. В. Федорова. - М. : РМАПО, 2006. - С. 43.

3. Охапкин М. Б. Антенатальная оценка зрелости легких плода при ультразвуковом исследовании / М. Б. Охапкин, М. В. Хитров, А. Р. Слепцов // Акушерство и гинекология. 1989. - № 1. - С. 21-23.

4. Титченко Л. И. Значение комплексного допплерометрического изучения маточно-плодово-плацентарного кровообращения в оценке внутриутробного состояния плода / Л. И. Титченко, Е. Е. Власова, М. А. Чечнева // Вестник Российской ассоциации акушеров-гинекологов. - 2000. № 1. - С. 50-52.

5. Сидорова И. С. Ехографрічні критерії розвитку плаценти / И. С. Сидорова, А. Н. Баранов, О. И. Волкова // Акушерство та гінекологія. - 1989. -№ 1. - С. 77-80.

6. Гулькевич Ю. Патология последа человека и ее влияние на плод / Ю. Гулькевич, М. Маккавеева, Б. Никифоров. - Минск : Белорусь, 1968. - 232 с.

7. Федорова М. В. Плацента и ее роль при беременности / М. В. Федорова, Е. П. Калашникова. - М. : Медицина, 1986. $-256 \mathrm{c}$.

8. Брусиловский А. И. Функциональная морфология плацентарного барьера человека / А. И. Брусиловский. К. : Здоров'я, 1976. - 135 с.

9. Савченков Ю. И. Очерки фризиологии и морфологии функциональной системи мать-плод / Ю. И. Савченков, К. С. Лобинцев. - М. : Медицина, 2000. - 254 с.

10. Маркін Л. Б. Біофрізичний моніторинг плода / Л. Б. Маркін, Б. М. Венцківський, К. В. Воронін. - Львів : Світ, 1993. -68 c

11. Порушення ліпідного складу і властивостей плазматичної мембрани епітеліальних клітин ворсинчастого хоріона плаценти під впливом хламідійної інфекції / С. В. Яблонська, С. П. Весельський, О. А. Кондратюк [та ін.]. // Український біохімічний журнал. - 2008. - Т. 80, № 2. - С. 135-140.

12. Громова А. М. Акушерські і антенатальні фрактори ризику внутрішньоутробного росту плода / А. М. Громова,

В. А. Бережна // Запорізький медичний журнал. - 2020. T. 22, № 3 (120). - C. 395-401.

13. Патогенетична роль дефіциту вітаміну Д та імунозапальних порушень у розвитку дистресу плода у вагітних із хронічним багатоводдям / Н. А. Гайструк, А. Н. Гайструк, Н. В. Мельник [та ін.] // Запорізький медичний журнал. -2019. - T. 21, № 5 (116). - С. 645-649.

14. Тимощук О. В. Простагландини - універсальні біорегулятори в організмі людини (огляд літератури) / О. В. Тимощук, І. С. Лембрик, З. Р. Кочерга // Запорізький медичний журнал. - 2018. - Т. 20, № 1 (106). - С. 121-127.

15. Шевченко А. О. Особливості акушерської та перинатальної патології на тлі загрози передчасних пологів / А. О. Шевченко // Запорізький медичний журнал. - 2017. T. 19, № 2 (101). - C. 190-194.

16. A new approach to the combination therapy of polycystic ovary syndrome / H. B. Semenyna, K. L. Shatylovych, T. V. Fartushok [et al.] // World of Medicine and Biology. - 2020. Vol. 2 (72). - C. 125-128.

17. Clementi M. The Euroscan study / M. Clementi, C. Stoll // Ultrasound Obstet. Gynecol. - 2001. - Vol. 18 (4). - P. 297-300.

18. Anderson N. Prenatal sonography for the detection of fetal anomalies: results of a prospective study and comparison with prior series / N. Anderson, O. Boswell, G. Duff // Am. J. Roentgenol. - 1995. - Vol. 65. - P. 943-950.

19. Schwarzler P. Feasibility of the second-trimester fetal ultrasound examination in an unselected population at 18, 20 or 22 weeks of pregnancy: are randomized trial / P. Schwarzler, M. Senat, D. Holden // Ultrasound Obstet. Gynecol. - 1999. Vol. 14 (2). - P. 92-97.

20. Gable S. Obstetrics: normal and problem pregnancies / S. Gable. - N.Y. : MeGraw, 2001. - 674 p.

21. Li C. Clinical study on morphological characteristics of placenta in severe pregnancy induced hypertension / C. Li, Z. Hu, Q. Tang // Zhonghua. Fu han. Ke. Za. Zhi. - 2000. Vol. 35 (11). - P. 651-653.

22. Greenwood S. Membrane potential difference and intracellular cation concentration in human placental trophoblast cells in culture / S. Greenwood, L. Crarson, M. Sibley. - Physiolog. - 1996. - Vol. 422-423. - P. 629-640.

23. Moore T. The amniotic fluid index in normal pregnancy / T. Moore, J. Cayle // Amer. J. Obstet. Gynecol. - 1990. Vol. 162. - P. 1168 
24. Phelan J. Amniotic fluid index assessment with fourquadrant technique at 36-42 weeks gestation / J. Phelan, C. Smith, P. Broussart // J. Reprod. Med. - 1987. - Vol. 32 (7). - P. 540-542.

\section{REFERENCES}

1. Mylovanov, A.P., Fuks, M.A., \& Chekhonatskaia, M.L. (1990). Morfologicheskye osobennosti ultrazvukovykh kriteryev stadii zrelosti platsenty pri fiziologicheskom techenii beremennosti [Morphological features of ultrasound criteria for the stage of maturity of the placenta in the physiological course of pregnancy]. Akusherstvo i ginekologiya - Obstet. and Gynecol., 5, 19-22 [in Russian].

2. Aheeva, M.Y., Ozerskaia, Y.Ia., \& Fedorova, E.V. (2006). Dopplerografiya platsentarnogo krovoobrashcheniya. Posobiye dlya vrachey [Doppler ultrasonography of the placental circulation. A guide for doctors]. Moscow: RMAPE [in Russian].

3. Okhapkyn, M.L., Khytrov, M.V., \& Sleptsov, A.R. (1989). Antenatalnaya otsenka zrelosty lehkykh ploda pry ultrazvukovom issledovanii [Antenatal assessment of fetal lung maturity by ultrasound]. Akusherstvo i ginekologiya - Obstet. and Gynecol., 1, 21-23 [in Russian].

4. Tytchenko L.Y., Vlasova E.E., \& Chechneva M.A. (2000) Znachenye kompleksnogo dopplerometricheskogo izucheniya matochno-plodovo-platsentarnogo krovoobrashcheniya v otsenke vnutryutrobnogo sostoyaniya ploda [The value of a complex Doppler study of the uterine-fetal-placental circulation in the assessment of the intrauterine state of the fetus]. Vestnik Rossiyskoy assotsiatsii akusherov-ginekologov - Bulletin of the Russian Association of Obstetricians and Gynecologists, 1 50-52 [in Russian].

5. Sydorova, Y.S., Baranov, A.N., \& Volkova, O.Y. (1989). Ekhohrafichni kryterii rozvytku platsenty [Echographic criteria for the development of the placenta]. Akusherstvo i ginekologiya Obstet. and Gynecol., 1, 77-80 [in Russian].

6. Hulkevych, Yu., Makkaveeva, M., \& Nykyforov, B. (1968). Patologiya posleda cheloveka i ee vliyanye na plod [Pathology of the human placenta and its effect on the fetus]. Minsk: Belarus [in Russian].

7. Fedorova, M.V., \& Kalashnykova, E.P. (1986). Platsenta $i$ ee rol pri beremennosty [Placenta and its role in pregnancy]. Moscow: Medicine [in Russian].

8. Brusylovskyi, A.Y. (1976). Funktsyonalnaya morfologiya platsentarnogo baryera cheloveka [Functional morphology of the human placental barrier]. Kyiv: Zdorovia [in Ukrainian].

9. Cavchenkov, Yu.Y., \& Lobyntsev, K.S. (2000). Ocherky fyzyolohyy y morfolohyy funktsyonalnoy symstemy mat-plod [Essays on the physiology and morphology of the functional system and mother-fetus]. Moscow: Meditsina [in Russian].

10. Markin, L.B., Ventskivskyi, B.M., \& Voronin, K.V. (1993). Biofizychnyi monitorynh ploda [Biophysical fetal monitoring]. Lviv: Svit [in Ukrainian].

11. Yablonska, S.V., Veselskyi, S.P., Kondratiuk, O.A., Fartushok, T.V., \& Besedin, V.M. (2008). Porushennia lipidnoho skladu i vlastyvostei plazmatychnoi membrany epitelialnykh klityn vorsynchastoho khorionu platsenty pid vplyvom khlamidiinoi infektsii [Destruction of the lipid storage and power of the plasma membrane of the epithelial cells of the villous chorion of the placenta due to the infusion of the clotted infection]. Ukrainskyi biokhimichnyi zhurnal - Ukrainian Biochemistry Journal, 80 (2), 135-140 [in Ukrainian].
25. Pijnenborg R. Placental bed Doppler spiral arteries in the hypertensive disorders of pregnancy / R. Pijnenborg, J. Anthony, D. Davey // Br. J. Obstet. Gynecol. - 1991. Vol. 98 (7). - P. 648-655.

12. Hromova, A.M., \& Berezhna, V.A. (2020). Akusherski i antenatalni faktory ryzyku vnutrishnoutrobnoho rostu ploda [Obstetric and antenatal factors of intrauterine growth of the fetus]. Zaporizkyi medychnyi zhurnal - Zaporozhye Medical Journal, 22, 3 (120), 395-401 [in Ukrainian].

13. Haistruk, N.A., Haistruk, A.N., Melnyk, N.V., Dubas, L.H., \& Lovkina, O.L. (1919). Patohenetychna rol defitsytu vitaminu $\mathrm{D}$ ta imunozapalnykh porushen u rozvytku dystresu ploda u vahitnykh iz khronichnym bahatovoddiam [The pathogenetic role of vitamin D deficiency and immunosuppressive breakdowns in the development of fetal distress in vaginal and chronic patients with poor health]. Zaporizkyi medychnyi zhurnal - Zaporizhzhia Medical Journal, 21, 5 (116), 645-649 [in Ukrainian].

14. Tymoshchuk, O.V., Lembryk, I.S., \& Kocherha, Z.R. (2018). Prostahlandyny - universalni biorehuliatory v orhanizmi liudyny (ohliad literatury) [Prostaglandins - universal bioregulators in the body of people (look around the literature)]. Zaporizkyi medychnyi zhurnal - Zapirozhzhia Medical Journal, 20, 1 (106), 121-127 [in Ukrainian].

15. Shevchenko, A.O. (2017). Osoblyvosti akusherskoi ta perynatalnoi patolohii na tli zahrozy peredchasnykh polohiv [Features of obstetric and perinatal pathology on the basis of contamination of the front canopy]. Zaporizkyi medychnyi zhurnal - Zaporizhzhia Medical Journal, 19, 2 (101), 190-194 [in Ukrainian].

16. Semenyna, H.B., Shatylovych, K.L., Fartushok, T.V., Komissarova, O.S., \& Yurchyshyn, O.M. (2020). A new approach to the combination therapy of polycystic ovary syndrome. World Medicine and Biology, 2 (72), 125-128.

17. Clementi, M., \& Stoll, C. (2001). The Euroscan study. Ultrasound Obstet. Gynecol., 18 (4), 297-300.

18. Anderson, N., Boswell, O., \& Duff, G. (1995). Prenatal sonography for the detection of fetal anomalies: results of a prospective study and comparison with prior series. Am. J. Roentgenol., 65, 943-950.

19. Schwarzler, P., Senat, M., \& Holden, D. (1999). Feasibility of the second-trimester fetal ultrasound examination in an unselected population at 18, 20 or 22 weeks of pregnancy: are randomized trial. Ultrasound Obstet. Gynecol., 14 (2), 92-97.

20. Gable, S. (2001). Obstetrics: normal and problem pregnancies. New York: MeGraw.

21. Li, C., Hu, Z., \& Tang Q. (2000). Clinical study on morphological characteristics of placenta in severe pregnancy induced hypertension. Zhonghua. Fu han. Ke. Za. Zhi., 35 (11), 651-653.

22. Greenwood, S., Crarson, L., \& Sibley, M. (1996). Membrane potential difference and intracellular cation concentration in human placental trophoblast cells in culture. Physiolog., 422-423, 629-640.

23. Moore, T., \& Cayle, J. (1990). The amniotic fluid index in normal pregnancy. Amer. J. Obstet. Gynecol., 162, 1168.

24. Phelan, J., Smith, C., \& Broussart, P. (1987). Amniotic fluid index assessment with four-quadrant technique at 36-42 weeks gestation. J. Reprod. Med., 32 (7), 540-542.

25. Pijnenborg, R., Anthony, J., \& Davey, D. (1991). Placental bed Doppler spiral arteries in the hypertensive disorders of pregnancy. Br. J. Obstet. Gynecol., 98 (7), 648-655.

Отримано 15.09.20

Прийнято до друку 16.10.20

Електронна адреса для листування: fartushok1@ukr.net 